\title{
Clinical Characteristics and Treatment of Oroantral Fistula
}

\author{
Sung Jae Heo, Kyung Jin Na, Hyun Soo Cho, Jin Hyun Ryu, Hyun Ho Cho, \\ Jin Hyuk Choi, Dong Hoon Kang, and Jung Soo Kim \\ Department of Otorhinolaryngology-Head and Neck Surgery, Kyungpook National University School of Medicine, Daegu, Korea
}

\section{구강 상악동 누공의 임상양상과 치료 분석}

허성재 · 나경진 · 조현수 · 류진현 · 조현호 · 최진혁 · 강동훈 · 김정수

경북대학교 의과대학 이비인후-두경부외과학교실

Received January 20, 2016

Revised May 26, 2016

Accepted June 22, 2016

Address for correspondence Jung Soo Kim, MD

Department of OtorhinolaryngologyHead and Neck Surgery,

Kyungpook National University

School of Medicine,

130 Dongdeok-ro, Jung-gu,

Daegu 41944, Korea

Tel $+82-53-420-5777$

Fax $+82-53-423-4524$

E-mail profsookim@gmail.com
Background and Objectives Oroantral fistula is an epithelialized communication between the oral cavity and the maxillary sinus. The aim of this study is to investigate the clinical characteristics and treatment of oroantral fistula.

Subjects and Method Patients who have undergone treatment for oroantral fistula between May 1995 and December 2015 were enrolled in this study. The demographic data of these patients and characteristics of oroantral fistula were analyzed. Patients with oroantral fistula were initially administered oral antibiotics for 3 weeks. If fistula persists in spite of the medication, surgery (soft tissue flap with or without bone graft) was performed. The surgical results according to the presence of bone graft were compared.

Results Twenty-two patients were in accordance with the inclusion criteria. The male to female ratio of patients was 12:10, with the mean age of $47.9 \pm 13.4$ years. The main complaint of patients was pus discharge from the fistula. Two patients were successfully treated with antibiotics whereas 20 patients underwent surgery. Recurrence occurred in 3 patients, who were treated with soft tissue flap, but no recurrence developed in the patients treated with soft tissue flap and bone graft. Although dehiscence of soft tissue flap occurred in one patient treated with bone graft, it was successfully treated by secondary intention without an additional surgery.

Conclusion Bone graft bears the negative pressure of the oral cavity and the weight of secretions including the blood. In addition, it induces secondary intention for the dehiscence of the flap. In this regard, bone graft seems to contribute to the surgical success of oroantral fistula. Korean J Otorhinolaryngol-Head Neck Surg 2016;59(8):593-8

Key Words Bone transplantation · Oral surgical procedures · Oroantral fistula Surgical flaps.

\section{서 론}

구강 상악동 교통(oroantal communication)은 구강과 상악 동이 연결된 것으로, 발치, 치아 이식, 종양 및 낭종 수술, Caldwell-Luc 수술, 골수염, 외상 등으로 인해 발생한다. ${ }^{1)}$ 구 강 상악동 교통이 발생했을 때 2일 내에 구강과 상악동의 연 결을 막는 치료를 해야 하며, 만약 이러한 연결이 지속되는
경우 구강 상악동 누공(oroantral fistula)이 발생한다. ${ }^{2)}$ 구강 상악동 누공이 발생하면 구강 내의 이물 및 세균이 누공을 통해 상악동으로 들어가서 만성 상악동염을 일으킬 수 있다. 상악동의 염증이 지속되면 누공이 자연적으로 막히지 않고, 이로 인해 상악동염이 지속되는 악순환을 하게 된다. 환자는 구강 상악동 누공과 만성 상악동염으로 인해 후비루, 비강과 구강 악취, 상악 부위의 통증, 콧물, 누공을 통한 농성 분비 
물 등을 흔히 호소한다. ${ }^{3)}$

구강 상악동 누공에서 상악동염이 없고 누공의 크기가 2 $\mathrm{mm}$ 이하인 경우에는 저절로 막힐 가능성이 높다. ${ }^{4}$ 누공의 크기가 2 5 mm인 경우에도 상악동염이 동반되지 않으면 저 절로 막히는 것을 기대해 볼 수 있다. ${ }^{5)}$ 하지만 $5 \mathrm{~mm}$ 이상으로 누공이 크거나, 누공의 크기와 상관없이 상악동염이 동반된 경우에는 수술적 치료가 구강 상악동 누공의 치료에 필수적 이다. 가장 대표적인 수술 방법은 협부 전진 피판(buccal advancement flap)과 구개 회전 피판(palatal rotational flap)을 이용한 것이고, 최근에는 협부 지방 패드(buccal fat pad), 골 이식 등이 사용되고 있다. ${ }^{1)}$ 국내 연구로 $\mathrm{SeO}$ 등 ${ }^{4)}$ 은 11 명의 구 강 상악동 누공 환자에서 협부 피판 및 구개 피판을 사용해 서 성공적으로 치료한 결과를 보고하였고, $\mathrm{Kim}$ 등6)은 장골 마개(iliac bone plug)를 이용하여 구강 상악동 누공을 치료 한 1 예를 보고하였다. 저자들은 협부 및 구개 피판을 사용하 여 치료한 환자에서 누공의 재발을 경험한 후부터, 골이식을 추가적으로 시행하고 있다.

구강 상악동 누공은 비교적 드문 질환으로, 임상양상 및 적 절한 치료법에 대한 연구가 부족하다. 특히, 치료법 간의 비교 연구는 매우 드물다. 이에 저자들은 구강 상악동 누공의 임상 양상을 알아보고, 골이식 유무에 따른 수술 결과를 비교해 보고자 하였다.

\section{대상 및 방법}

1995년 5월부터 2015년 12월까지 본원 이비인후과에서 구 강 상악동 누공으로 치료받은 환자들을 대상으로 하였고, 추적관찰 기간이 6개월 미만이거나 조절되지 않은 당뇨나 교 원질병(collagen disease)와 같이 상처 치유에 영향을 주는 질
환이 있는 환자들은 제외하였다. 의무기록을 후향적으로 분 석해서 환자의 나이, 성별, 증상, 누공의 원인, 이환 기간, 누공 의 위치와 크기, 치료 방법, 합병증, 재발 여부를 알아보았다. 합병증은 수술 3 개월 이내 수술 부위의 출혈, 감염, 봉합의 벌어짐, 피판의 괴사가 발생한 경우로 정하였고, 재발은 누공 이 막힌 후 3 개월 이상 지나서 다시 동일한 부위에 누공이 발 생한 경우로 정하였다. 내원 당시 촬영한 부비동 전산화단층 촬영의 골결손 크기로 누공의 크기를 결정하였고, 영상 분석 을 통해 구강과 연결되어 있는 상악동에 부비동염이 동반되 어 있는지 확인하였다.

치료원칙은 다음과 같다(Fig. 1). 구강 상악동 누공이 발생 한지 3 주 이내의 급성기인 경우에는 3 주간 항생제 치료 후 누 공을 재평가하였다. 3 주 후 누공이 막히면 추가적인 치료 없 이 경과관찰 하였고, 누공의 크기가 줄어들면 항생제를 추가 적으로 투여하였으며, 누공 크기의 변화가 없으면 수술을 계 획하였다. 수술방법은 2010년 3월 이전에는 일차 봉합법에 실 패하거나 누공의 크기가 $2 \mathrm{~mm}$ 이상인 경우에 협부 및 구개 피판법을 시행하였다. 2010년 3월 이후부터는 모든 구강 상악 동 누공 수술에 골이식편을 끼워맞춤(press-fit closure)으로 누공을 막은 후 협부 전진 피판을 하는 방법을 사용하였다 (Figs. 2, 3, and 4). 골이식은 $10 \mathrm{~mm}$ 이하 크기의 누공은 상 악골이나 비갑개골(nasal turbinate bone)을 이용하였고, 그 이상 크기의 누공에서는 장골(iliac bone)을 이용하여 골이식 을 하였다. 비갑개골은 주로 하비갑개골을 이용하였고, 만약 하비갑개골이 이식에 적절치 못하거나 충분한 양을 얻을 수 없는 경우에는 중비갑개골을 사용하였다. 수술을 시행한 모 든 예에서 구강 상악동 누공을 막는 수술을 할 때 내시경적 상악동절개술을 함께 시행하였다.

치료법 간 비교를 위해, 골이식을 시행하지 않은 그룹과 골이

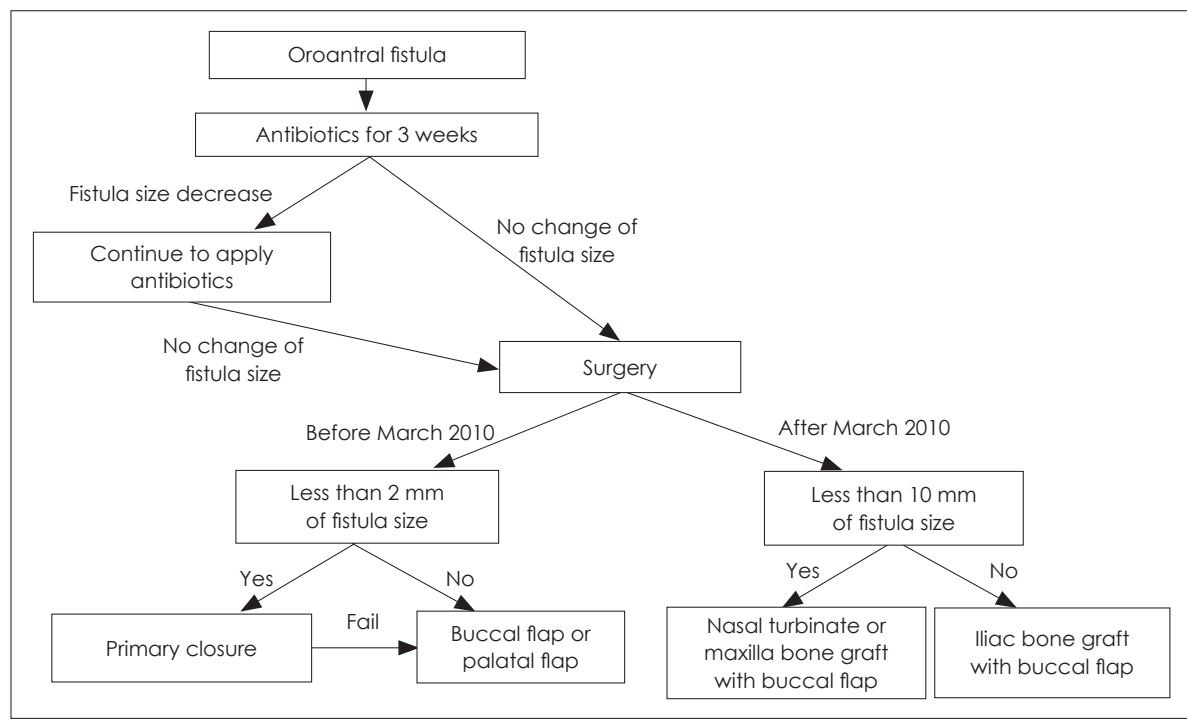

Fig. 1. Treatment flow of oroantral fistula. 
식을 시행한 그룹으로 나누어 합병증과 재발 여부를 비교 분 석하였다. 통계는 SPSS statistics version 18.0(SPSS Inc., Chi- cago, IL, USA)을 사용하였다. 나이, 이환 기간, 누공의 크기 는 평균과 표준편차, 범위를 제시하였고, 골이식을 한 그룹과
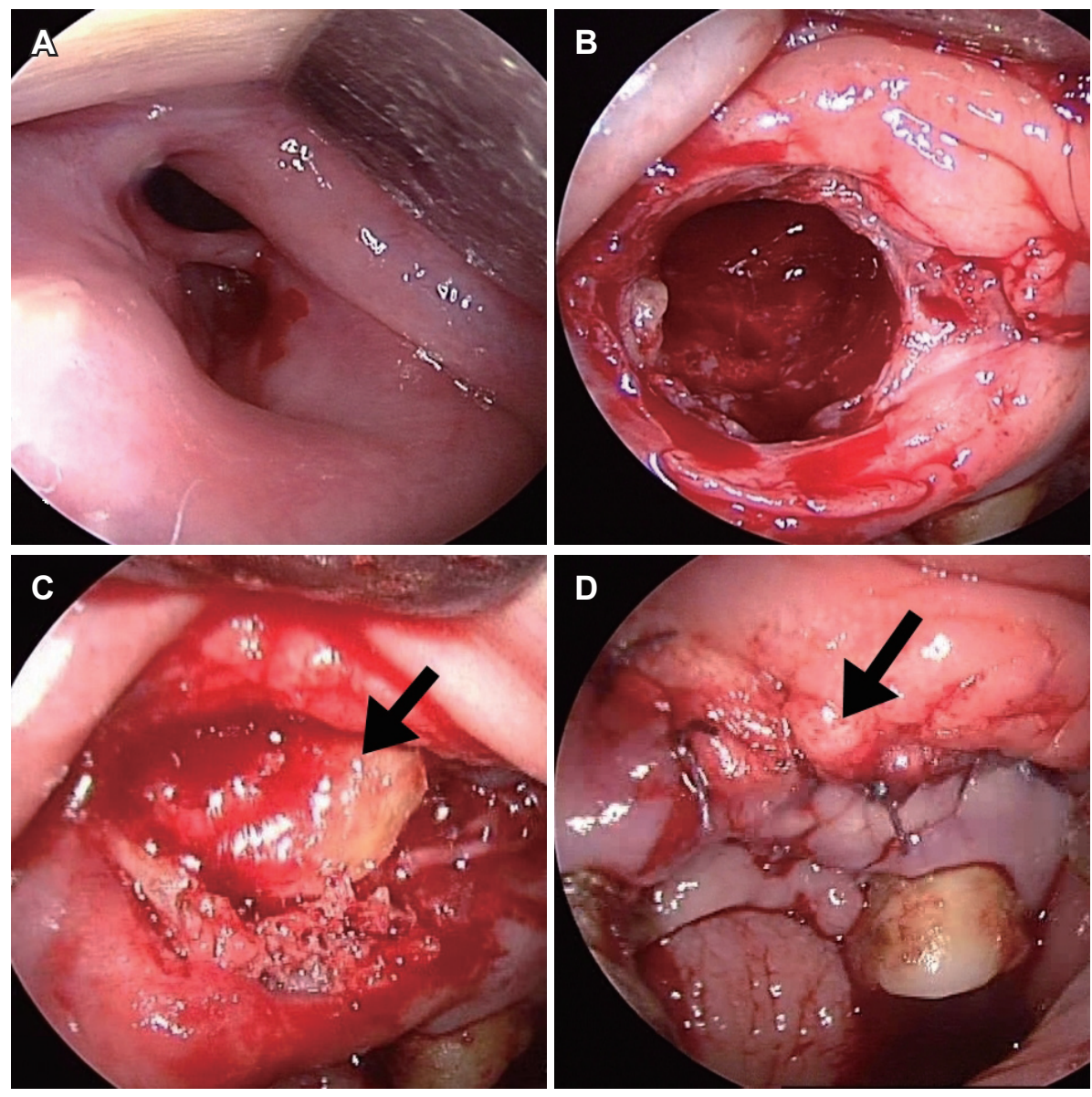

Fig. 2. Intraoperative findings. Oroantral fistula connects the oral cavity and the maxillary sinus (A). Fistulectomy was performed (B). lliac bone (arrow) was press-fitted into the defect (C). Buccal flap (arrow) was advanced to cover the bone graft plugging fistula (D).

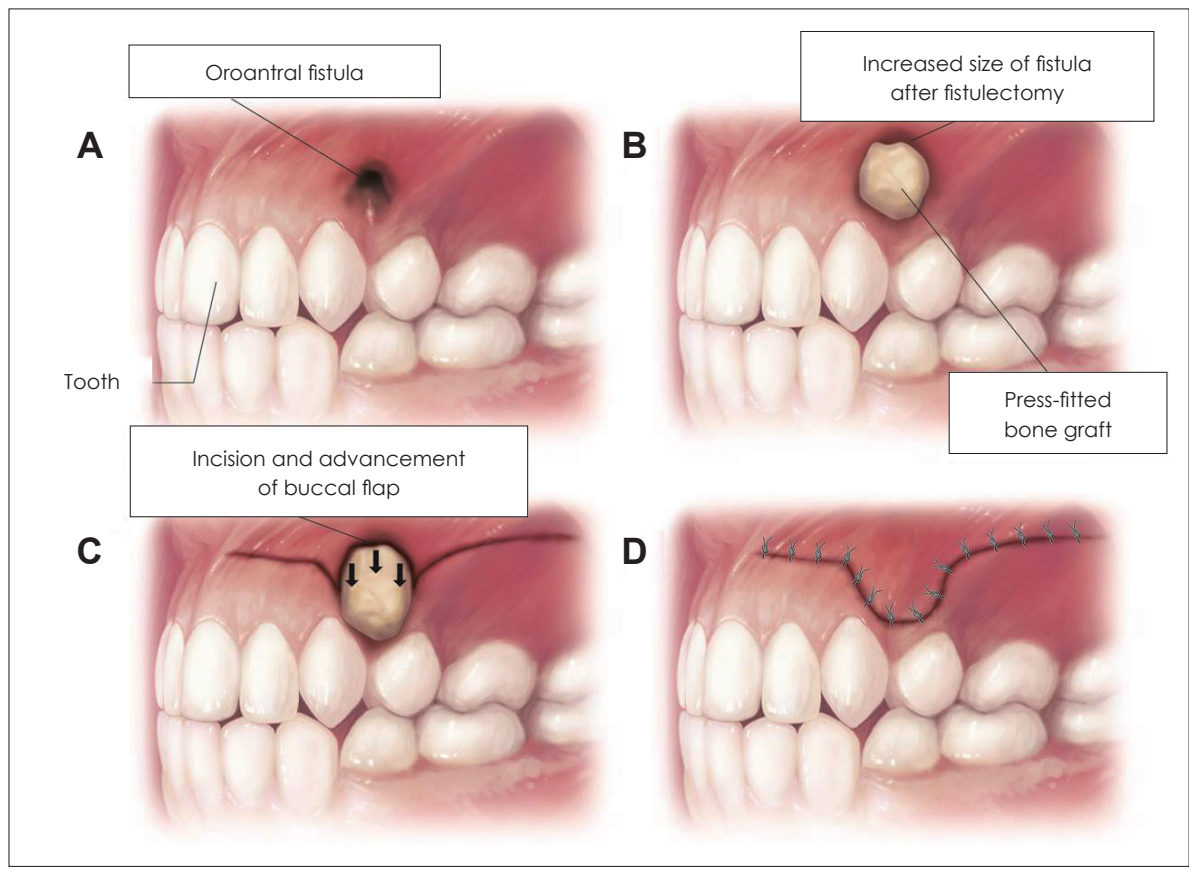

Fig. 3. Schematic drawing of bone graft with buccal advancement flap. Oroantral fistula is located at the anterior wall of maxilla (A). Size of oroantral fistula increased after fistulectomy and bone graft was pressfitted into fistula (B). Incision was performed at the upper margin and both sides of fistula to make buccal flap and the flap was advanced to cover the bone graft $(C)$. Buccal flap was sutured and fistula was completely closed (D). 

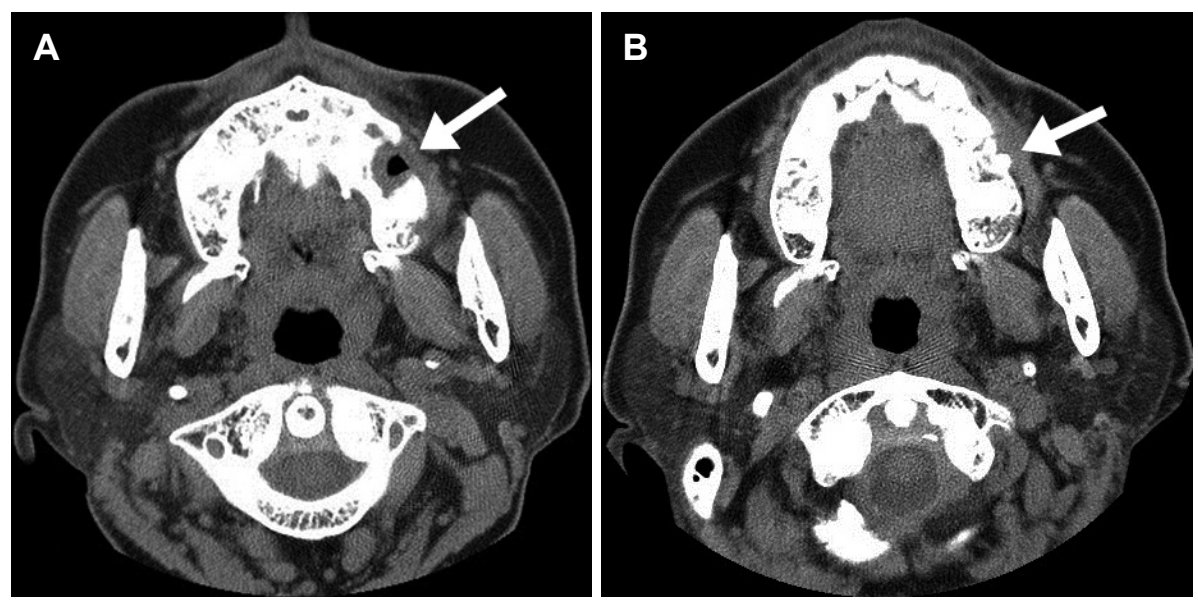

Fig. 4. An axial computed tomography scan. Oroantral fistula (arrow) is shown in the left maxilla bone (A). Bone graft (arrow) fills the defect (B).

안 한 그룹 간의 비모수 변수 비교는 Mann-Whitney 검정을 이용하였다. 골이식 유무에 따른 합병증과 재발률의 비교는 Fisher 정확검정을 이용하였고, $p$ value가 0.05 미만인 경우 에 유의한 것으로 판단하였다. 본 연구는 본원의 기관윤리심 의위원회의 승인을 받고 진행하였다(IRB No. 2015-11-016).

\section{결 과}

포함제외기준을 충족한 22 명의 환자가 연구에 포함되었다. 남자는 12 명, 여자는 10 명이었고, 평균 나이는 $47.9 \pm 13.4$ 세였 다. 구강 상악동 누공의 평균 이환 기간은 $9.5 \pm 10.3$ 개월이었 으며, 누공의 크기는 평균 $5.6 \pm 3.2 \mathrm{~mm}$ 였다(Table 1). 누공은 우측(9명)에 비해 좌측(13명)에 많이 발생했고, 주된 증상은 구강 쪽 누공 입구에서 농성 분비물(68.2\%)이 나오는 것이었 고, 구강의 액체가 비강으로 역류하는 증상이 다음으로 흔 하였다. 누공의 가장 흔한 원인은 발치(72.7\%)였고, 그 외 Caldwell-Luc 수술 후 발치, 치성 낭종 수술이 원인이었다. 누공의 위치는 제1대구치, 제2대구치, 제 1 소구치, 제 2 소구치 순으로 높은 빈도를 보였다. 내원 당시 촬영한 부비동 전산화 단층촬영에서 2 명을 제외한 20명의 환자(90.9\%)에서 부비동 염 소견이 관찰되었고, 20 명 중 8 명에서는 공기액체층(air fluid level) 또는 기포(air bubble)가 관찰되었고, 나머지 12 명에서는 점막골막비후(mucoperiosteal thickening)와 상악 골 비후가 있었다.

전체 환자 중 2 명에서는 항생제 치료만으로 누공이 막혀서 치료를 종료하였고, 나머지 20명에서 수술을 시행하였다. 장골 이식을 한 수술을 제외한 경우들에서는 환자의 선호도에 따 라 마취 종류를 선택하였고, 전신마취는 8 명, 부분마취는 12 명에서 시행되었다. 골이식을 시행하지 않은 환자는 11 명이었 고, 그 중 2 명의 환자에서는 일차 봉합, 3 명의 환자에서는 구 개 회전 피판, 6 명의 환자에서 협부 전진 피판을 시행하였다.
Table 1. Patient characteristics at baseline $(n=22)$

\begin{tabular}{|c|c|c|}
\hline Variables & Mean \pm SD & $\begin{array}{l}\text { Range or } \\
\text { percentage }\end{array}$ \\
\hline Gender, male/female & $12 / 10$ & \\
\hline Age (yr) & $47.9 \pm 13.4$ & $19-69$ \\
\hline Duration (mo) & $9.5 \pm 10.3$ & $1.0-33.0$ \\
\hline Size $(\mathrm{mm})$ & $5.6 \pm 3.2$ & $2-13$ \\
\hline \multicolumn{3}{|l|}{ Chief complaint } \\
\hline Pus discharge from fistula & 15 & 68.2 \\
\hline Reflux from oral to nasal cavity & 4 & 18.2 \\
\hline Foul odor & 2 & 9.1 \\
\hline Facial pain & 1 & 4.5 \\
\hline \multicolumn{3}{|l|}{ Cause } \\
\hline Tooth extraction & 16 & 72.7 \\
\hline $\begin{array}{l}\text { Tooth extraction with } \\
\text { Caldwell-Luc operation }\end{array}$ & 4 & 18.2 \\
\hline Dentigerous cyst & 2 & 9.1 \\
\hline \multicolumn{3}{|l|}{ Location } \\
\hline First premolar & 4 & 18.2 \\
\hline Second premolar & 2 & 9.1 \\
\hline First molar & 10 & 45.5 \\
\hline Second molar & 6 & 27.2 \\
\hline \multicolumn{3}{|l|}{ Treatment } \\
\hline Antibiotics medication & 2 & 9.1 \\
\hline Primary closure & 2 & 9.1 \\
\hline Buccal advancement flap & 6 & 27.2 \\
\hline Palatal rotational flap & 3 & 13.6 \\
\hline $\begin{array}{l}\text { Buccal advancement flap } \\
\text { with bone graft }\end{array}$ & 9 & 41.0 \\
\hline
\end{tabular}

Continuous data are presented as number or mean with range. SD: standard deviation

골이식은 9명의 환자에서 시행되었고, 모든 환자에서 골이식 후 협부 전진 피판술을 시행하였다. 이식한 골의 종류로, 2 명 의 환자에서는 상악골, 3 명의 환자에서 장골, 4 명의 환자에서 비갑개골을 이용하였다.

골이식을 시행하지 않은 환자 중 1명에서는 수술 2주 후에 
Table 2. Comparison of surgical results of oroantral fistula according to the presence of bone graft

\begin{tabular}{lccc}
\hline & Oroantral fistula closure without bone graft $(n=11)$ & Oroantral fistula closure with bone graft $(n=9)$ & $p$-value \\
\hline Complication & $1^{*}$ & $1^{*}$ & 1.000 \\
Recurrence & 3 & 0 & 0.218 \\
\hline
\end{tabular}

*wound dehiscence

구개 피판 봉합부위가 벌어져서 협부 피판으로 재수술을 시 행하였다. 골이식을 시행한 환자 중 1명에서는 수술 2주 후 피 판 봉합부위가 벌어졌으나 이식한 골 위로 이차 유합(secondary intention)이 일어나서 추가적 처치 없이 누공이 막혔 다. 재발은 골이식을 시행하지 않은 환자들 중 3명에서 발생 하였으나, 골이식을 시행한 환자들에서는 발생하지 않았다. 골이식 여부에 따른 합병증과 재발률에 통계적으로 유의한 차이는 보이지 않았다(Table 2).

\section{고 찰}

구강 상악동 누공의 치료 방법에는 다양한 의견들이 있다. 누공 발생 후 즉시 막지 않으면 48시간 내에는 50\%에서, 2주 이후에는 $90 \%$ 에서 부비동염이 발생하기 때문에, 누공 발생 24시간 내에 수술적 치료를 해야 한다는 주장이 있다.' 그에 반해, 누공의 크기가 $2 \mathrm{~mm}$ 정도로 작고 부비동염이 동반되 지 않은 경우에는, 초기에 약물치료만으로 누공이 막힐 수 있어서 최소 3 주는 약물치료를 우선적으로 해야 한다는 주 장도 있다. ${ }^{6)}$ 하지만, 이러한 주장들의 근거가 부족하고 누공 크기에 대한 기준도 명확하지 않아서, 구강 상악동 누공은 치료 가이드라인이 확립되어 있지 않다. ${ }^{1)}$ 본 연구의 환자 중 에서 보전적 치료로 누공이 막힌 2예(크기는 각각 $2,3 \mathrm{~mm}$ ) 의 경우, 누공이 발생한지 각각 4, 7주가 지났지만 3 4주의 항 생제 치료로 누공이 막히고 동반된 상악동염 또한 호전되었 다. 보통 누공이 발생한지 3주가 지났거나 상악동염이 있는 경 우에는 약물치료로 누공이 막히기 어렵다고 알려져 있지만, 이러한 경우에도 항생제 치료만으로 누공이 막힌 것을 봤을 때, 발생한지 3주가 지났고 상악동염이 동반되어 있더라도 작 은 크기의 누공에서는 항생제 치료를 우선적으로 시도해보 는 것이 좋을 것으로 생각된다.

본 연구에서 누공의 재발은 골이식을 하지 않고 협부 및 구 개 피판만으로 수술한 11 명의 환자 중 3예(협부 피판 2예, 구 개 피판 1예)에서 발생했다. 이러한 결과는 이전에 문헌들에 보고된 구개 및 협부 피판의 성공률(70 80\%)과 일치한다. ${ }^{1)}$ 재발환 환자들의 처음 내원 당시 누공 크기는 각각 $4,5,7 \mathrm{~mm}$ 였고, 2 명은 흡연자였으며 1 명은 평소 구강내 음압을 만드는 습관이 있었다. 재발 시점은 각각 수술 후 5, 7, 10개월이었다. 수술 후 코풀기나 입안에 음압을 만드는 행동을 하지 말 것
을 교육하였지만, 시간이 지날수록 환자들이 평소 습관대로 생활하여서 이와 같은 재발이 발생한 것으로 보인다. 이러한 경험으로 저자들은 2010년 3월부터 연조직(soft tissue) 피판 에 골이식을 추가적으로 시행하고 있고, 골이식을 함께 시행 한 환자들에서는 재발이 없었다.

골이식의 장점으로는 첫째, 압력에 저항하는 지지대 역할 을 한다. 환자의 코풀기나 습관에 의한 음압과 같은 압력뿐 만 아니라, 수술에 의해 분비되는 피나 삼출액에 의한 무게를 지탱해서 이식물의 이탈을 막을 수 있다.9) 둘째, 연조직 피판이 벌어지거나 괴사되는 문제가 발생해도 이식된 골이 판(plate) 역할을 해서 이차 유합을 유도할 수 있다. 본 연구의 1 예에서 도 피판 봉합이 벌어졌지만 추가적 치료 없이도 골이식편 위 로 점막상피가 생성되어 누공은 성공적으로 막혔다. 이러한 결과는 Haas 등 ${ }^{7)}$ 과 $\mathrm{Er}$ 등 $^{1}$ 의 연구와 일치한다. 셋째, 구강 점 막과 상악동 점막(Schneiderian membrane)의 결합(fusion) 또는 엉킴(matting)을 막을 수 있다. 많은 구강 상악동 누공 환 자들이 누공 치료 후 임플란트를 계획하는데, 누공이 있었던 부위는 임플란트를 고정할 치조골이 없거나 부족하기 때문에 상악동 거상술(sinus lifting) 시행 후 골이식을 해야 한다. 구 강 상악동 누공을 연조직 이식으로만 치료한 경우 구강 점막 과 상악동 점막의 결합 또는 엉킴이 발생하고, 이로 인해 상 악동 거상술 과정에서 필연적으로 상악동 점막 손상이 일어 난다. 골이식을 하면 구강점막과 상악동 점막을 분리시킬 수 있어서 이러한 문제점을 막을 수 있다.

골이식 재료로 하악골, 상악골, 광대돌기, 비갑개골, 장골 등 다양하게 사용될 수 있는데, ${ }^{10)}$ 저자들은 크기가 $10 \mathrm{~mm}$ 미만의 누공에서는 비갑개골을 골이식 재료로 사용했고, 그 이상 크기의 누공에서는 장골을 사용하였다. 비갑개골은 다 른 골이식 재료들에 비해 강도가 떨어지지만 비교적 쉽고 적 은 이환율로 채취가 가능한 장점이 있어서, 적은 양의 골이 필요한 경우 사용하였다. 장골은 골이식 재료들 중 공여부의 통증이 비교적 심하고 수술 부위가 다른 단점이 있지만, 충분 한 양의 골을 얻을 수 있는 장점이 있다.

골이식의 성공에 가장 중요한 것은 골이식편이 누공에 꼭 맞게 고정되는 것이다. 이를 위해서 누공의 크기는 전산화단 층촬영에서 보이는 골결손 크기로 측정해야 하고, 측정된 크 기보다 크게 채취해야 한다. 누공을 덮고 있는 상피는 수술 시 제거되므로 실제 누공의 크기는 구강에서 관찰되는 것보 
다 크고, 골이식편을 재단하는 과정에서 채취한 골 크기는 작아지므로 충분한 크기의 골을 채취해야 한다. 채취한 골이 식편을 재단할 때에는 누공 주변 구조물과의 마찰을 크게 하 기 위해 표면은 거칠게 만드는 것이 좋고, 코르크 마개처럼 한쪽 끝과 반대편 끝의 크기를 다르게 재단하면 쉽게 이식편 을 누공에 꼭 맞게 고정시킬 수 있다. 골이식편이 누공에 고정 되지 않으면 골나사(bone screw)나 작은판(miniplate)을 사용 해서 고정해야 하지만 본 연구에서는 이러한 추가적 고정장 치가 필요하지 않았다. Haas 등ㄱㅇㅢ 연구에서는 5명의 환자 중 2 명에서 골이식편의 고정을 위해 골나사와 작은판을 사용했 지만, $\operatorname{Er}$ 등 $^{1}$ 의 연구에서는 10 명의 환자 중 추가적 고정이 필 요한 환자는 없었다.

본 연구의 한계점으로 첫째, 후향적 연구이고 연구대상 수 가 적다. 둘째, 수술이 단일 술자에 의해 시행되지 않았고, 3 명의 의사에 의해 시행되었다. 하지만, 동일한 수술법에 의해 서 수술이 이루어졌기 때문에 결과에 큰 영향을 주지는 않 았을 것으로 생각된다. 셋째, 비교분석을 한 골이식을 시행하 지 않은 군과 시행한 군 사이에 누공의 크기와 추적관찰 기간 에 차이가 있다. 하지만, 누공의 평균 크기가 더 작은 군(골이 식을 시행하지 않은 군)에서 3명의 재발이 있었기 때문에, 본 연구에서는 누공의 크기가 재발에 많은 영향을 주지 않았을 것으로 보인다. 또한, 재발 발생 시점이(수술 후 $5,7,10$ 개월) 환자들의 최소 추적관찰 기간인 11 개월 내에 모두 포함되므 로, 추적관찰 기간이 재발률 차이에 미친 영향은 크기 않았 을 것으로 보인다.

구강 상악동 누공에서 이식된 골편은 피와 같은 분비물의 무게로부터 봉합부위를 보호해주고, 점막재생의 판으로서의 역할을 한다. 또한, 구강내 음압에 저항하여 재발을 줄이는
역할을 하는 것으로 생각된다. 이러한 장점들은 수술시간 및 회복기간의 연장, 공여부의 통증과 같은 단점을 감안하더라 도 시행할 충분한 가치가 있다고 여겨진다. 좀 더 정확한 분 석을 위해서는 많은 표본을 대상으로 한 무작위 비교 연구가 이루어져야 한다.

\section{Acknowledgments}

This study was supported by a research grant of Kyungpook National University

\section{REFERENCES}

1) Er N, Tuncer HY, Karaca C, Copuroğlu S. Treatment of oroantral fistulas using bony press-fit technique. J Oral Maxillofac Surg 2013; 71(4):659-66.

2) Yalçın S, Oncü B, Emes Y, Atalay B, Aktaş I. Surgical treatment of oroantral fistulas: a clinical study of 23 cases. J Oral Maxillofac Surg 2011;69(2):333-9.

3) Candamourty R, Jain MK, Sankar K, Babu MR. Double-layered closure of oroantral fistula using buccal fat pad and buccal advancement flap. J Nat Sci Biol Med 2012;3(2):203-5.

4) Seo M, Kim YJ, Kim JH, Lee BJ. Treatment outcome of oroantral fistula. Korean J Otolaryngol-Head Neck Surg 2002;45(1):47-50.

5) Dym H, Wolf JC. Oroantral communication. Oral Maxillofac Surg Clin North Am 2012;24(2):239-47, viii-ix.

6) Kim JK, Shim DB, Cho WP, Sinn DH. A case of large oroantral fistula repair using iliac bone plug. Korean J Otolaryngol-Head Neck Surg 2004:47(8):791-4

7) Haas R, Watzak G, Baron M, Tepper G, Mailath G, Watzek G. A preliminary study of monocortical bone grafts for oroantral fistula closure. Oral Surg Oral Med Oral Pathol Oral Radiol Endod 2003; 96(3):263-6.

8) Yang SM, Park CH, Lee JH. A case of oroantral fistula complicating fungal sinusitis. J Rhinol 2007;14(1):56-9.

9) Saleh EA, Issa IA. Closure of large oroantral fistulas using septal cartilage. Otolaryngol Head Neck Surg 2013;148(6):1048-50.

10) Visscher SH, van Minnen B, Bos RR. Closure of oroantral communications: a review of the literature. J Oral Maxillofac Surg 2010;68(6):1384-91. 